\title{
Variation of CYP2C9 Gene and Glycemic Control in Diabetic Patients: A Literature Review
}

\author{
Nidaul Makwa ${ }^{1}$ Dyah A Perwitasari ${ }^{2 *}$ Imaniar N Faridah $^{3}$ Lalu M Irham ${ }^{4}$ Haafizah \\ Dania $^{5}$ Rita Maliza ${ }^{6}$
}

\author{
1,2,3,4,5 Faculty of Pharmacy, Universitas Ahmad Dahlan, Yogyakarta \\ ${ }^{6}$ Program Study of Biology, Faculty of Applied Science and Technology, Universitas Ahmad Dahlan, Yogyakarta \\ *Dyah Aryani Perwitasari.Email: dyah.perwitasari@pharm.uad.ac.id
}

\begin{abstract}
The prevalence of Diabetes Mellitus Type 2 (DMT2) is continuing to increase worldwide. The variety of responses to the oral antidiabetic is influenced by several factors, including genetics, physiology, pathophysiology and the environment. Genetic factors are estimated to contribute 15-30\% to differences in metabolism and drug response between individuals. The purpose of this study was to determine the variation of the $C Y P 2 C 9$ gene in DMT2 patients and its association with glycemic control. The method used in this research was literature review. Keywords used for collecting the articles were "CYP2C 9 , diabetes mellitus, type 2, oral antidiabetic". Article search was conducted on Google Scholar, PubMed and several international journal providers. The inclusion criteria were articles published in the last 20 years (2000-2020) that addressed the variance and polymorphism of CYP2C9 in DMT2 patients and could be reviewed in full text, including national and international journals. The exclusion criteria in this research were articles that are not original articles. The analysis in this study was performed by describing the qualitative and quantitative results of the journal studies reviewed. We found 13 articles that met the inclusion criteria. The DMT2 patients included in the study were from India, Slovenia, Russia, Mexico, China, Turkey, Egypt, Israel, Greece, Netherlands, Japan, United Kingdom and Germany. Most of the allele variants found were CYP2C9*2 and CYP2C9*3 with heterozygous genotype CYP2C9*1/*2, CYP2C $9 * 1 / * 3$ and heterozygous genotype due to two allele polymorphisms, namely CYP2C9*2/*3. Homozygous genotypes found were CYP2C $9 * 1 / * 1$ (normal genotype) and genotypes due to 2 allele polymorphisms namely CYP2C $* 2 / * 2$ and CYP2C $* 3 / * 3$. The DMT2 patients with polymorphism experienced better glycemia control than DMT2 patients with the normal genotype. However, those with CYP2C $9 * 2$ and CYP2C $9 * 3$ polymorphisms experienced higher risk of hypoglycemia.

The DMT2 patients mostly have normal CYP2C $9 * 1 / * 1$ genotype, requiring definition of adjustment of dose of oral antidiabetic to obtain the optimal therapeutic effect. However, the hypoglycaemic risk must be closely monitored for DMT2 patients with CYP2C9*2 and CYP2C9*3.
\end{abstract}

Keywords: diabetes mellitus type 2, CYP2C9, review

\section{INTRODUCTION}

Epidemiologic data of DMT2 shows an increased prevalence, at a rate of about 21.3 million Indonesian patients in 2030 [1]. Data published in 2013 reported an increased prevalence of DMT2 (based on physician diagnosis in patients with age $\geq 15$ years) of $2 \%$, in comparison to data from The Indonesia Basic Health Research in 2018 [2]. Currently, the prevalence in all criteria of ages is lower than prevalence of DMT2 in patients aged $\geq 15$ years old, which is $1.5 \%$ [3].

The most common treatment of DMT2 is oral hypoglycemic agents or insulin depending on disease severity [4]. Oral hypoglycemic agents (OHA) commonly used are sulphonylurea, metformin or a combination. Sulphonylureas, such as glibenclamide, has a mechanism to increase insulin secretion by beta cells in the pancreas. On the other hand, metformin has been known to reduce hepatic glucose production (gluconeogenesis). Combination of these drugs is also possible as a treatment if single treatment is not responsive [5]. The metabolic process of OHA results in different response individually and is related to factors such as genetics, physiology, pathophysiology and environmental. In general, genetics accounts for approximately 15-30\% of factors that contribute to different responses in metabolic process and response to drug. The CYP2C9 and CYP2C19 are responsible for sulphonylurea metabolism [6], however CYP2C9 is also important in the hydroxylation of glibenclamide.

The purpose of this study is to determine the genotype description of CYP2C9 in DMT2 patients in different countries as a risk factor for this disease. Furthermore, this study will also determine the association between CYP2C9 gene and glycemic control. 


\section{METHODS}

\subsection{Search Strategy}

This study used a narrative review method. The database used to search articles in this review were open educational resources and website such as PubMed, MDPI, Google Scholar, DOAJ and Nature. Keywords used to locate target journals are displayed in Table 1 and the process of literature searching is displayed in Figure 1.

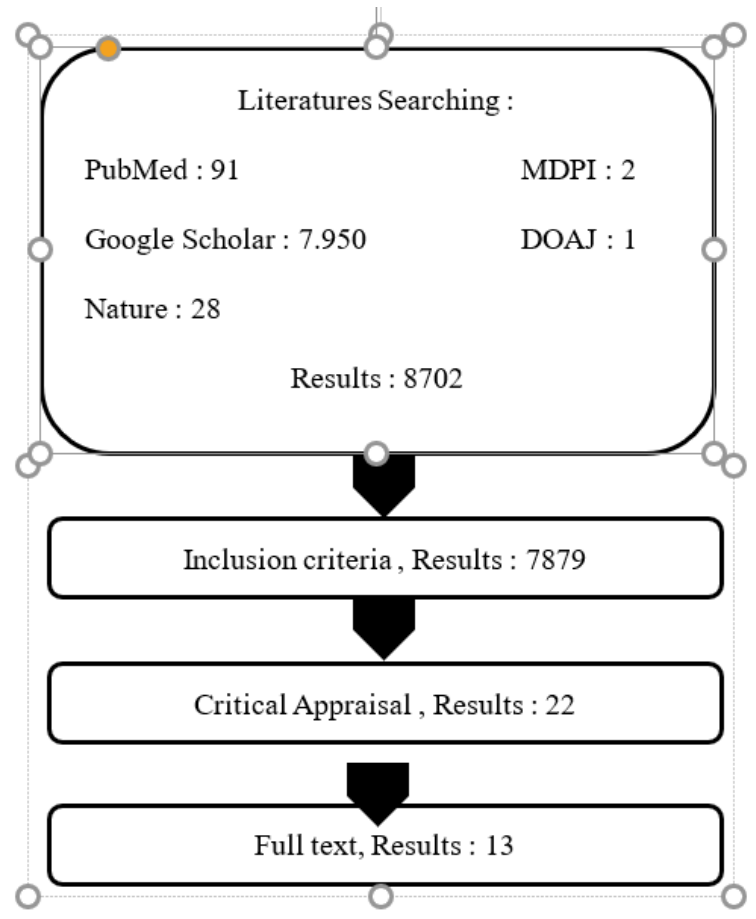

Figure 1. Process of literature searching

\subsection{Inclusion and Exclusion Criteria}

Inclusion criteria of this study were as follows: (1) articles published in the last 20 years (2000-2020), (2) articles describing CYP2C9 genotype study in patients with Type 2 diabetes mellitus taking oral antidiabetics, (3) articles available as full text, and (4) articles providing outcome therapy (related to diabetic status or hypoglycemic effect). Moreover, the exclusion criteria were non-original articles, such as commentaries, case reports, systematic reviews or meta-analyses. Critical appraisal was conducted to screen the articles based on the research question, internal validity and minimal risk of bias.

\subsection{Data Extraction}

Data from studies that met the inclusion criteria were extracted independently. We found 7,879 articles that met the inclusion criteria. Regarding the characteristic study, data collected included title, author, the year of publication, number of samples, kind of oral antidiabetic, method of the study, variants genotype in CYP2C9 and outcome therapy, which related to diabetic status (controlled or uncontrolled diabetes) or hypoglycemic effect (Table 1).

Table 1. Keywords used in databases

\begin{tabular}{|c|c|c|}
\hline Database & Keywords & $\begin{array}{l}\text { Articles } \\
\text { found }\end{array}$ \\
\hline PubMed & $\begin{array}{l}\text { "diabetes mellitus, type } 2 \text { " OR "type } \\
2 \text { diabetes mellitus" AND } \\
\text { "CYP2C9" }\end{array}$ & 59 \\
\hline PubMed & $\begin{array}{l}\text { "diabetes mellitus, type 2" OR "type } \\
2 \text { diabetes mellitus" AND } \\
\text { "hypoglycemic agent" OR } \\
\text { "antidiabetic" OR "sulphonylurea" } \\
\text { AND "CYP2C9" AND "blood sugar } \\
\text { levels" OR "blood glucose levels" }\end{array}$ & 15 \\
\hline PubMed & $\begin{array}{l}\text { "CYP2C9" AND “diabetes mellitus } \\
\text { type } 2 \text { " AND "glibenclamide" OR } \\
\text { "oral antidiabetic" AND } \\
\text { "metformin" OR "oral antidiabetic" }\end{array}$ & 7 \\
\hline PubMed & $\begin{array}{l}\text { "CYP2C9" AND "antidiabetic" } \\
\text { AND "type } 2 \text { diabetes patients" }\end{array}$ & 1 \\
\hline PubMed & $\begin{array}{l}\text { "diabetes mellitus type 2" AND } \\
\text { "cyp } 2 \text { c9 polymorphism" AND "oral } \\
\text { antidiabetic" } A N D \text { "effectiveness" }\end{array}$ & 9 \\
\hline $\begin{array}{l}\text { Google } \\
\text { Scholar }\end{array}$ & $\begin{array}{l}\text { "cyp } 2 \text { c9, type } 2 \text { diabetes mellitus, } \\
\text { antidiabetic oral, fasting glucose } \\
\text { levels" }\end{array}$ & 7.950 \\
\hline Nature & $\begin{array}{l}\text { "type } 2 \text { diabetes mellitus, CYP2C9, } \\
\text { blood glucose levels" }\end{array}$ & 28 \\
\hline MDPI & $\begin{array}{l}\text { "CYP2C9" AND “type } 2 \text { diabetes } \\
\text { mellitus" OR "diabetes mellitus, type } \\
2 \text { " AND "sulphonylurea" AND } \\
\text { "blood glucose levels" }\end{array}$ & 2 \\
\hline DOAJ & $\begin{array}{l}\text { "type } 2 \text { diabetes mellitus, } \\
\text { antidiabetic oral, CYP2C9" }\end{array}$ & 1 \\
\hline \multicolumn{2}{|c|}{ Number of articles found prior to exclusion } & 8.072 \\
\hline
\end{tabular}

\section{RESULTS}

We reviewed 13 articles that met the inclusion criteria (Figure 1). All of the articles reviewed were original, 10 of which were cohort studies $(76.9 \%)$, two cross-sectional studies $(15.4 \%)$ and one case control study (7.7\%). Based on the distribution area or setting place of the journal, articles showed that an even spread in many countries, including India, Slovenia, Russia, Mexico, China, Turkey, Egypt, Israel, Greece, Netherlands, Japan, UK and Germany (Table 2). 
Table 2. Result from extraction data

\begin{tabular}{|c|c|c|c|c|c|c|}
\hline No & $\begin{array}{l}\text { The Title, Author, } \\
\text { and The year of } \\
\text { publication }\end{array}$ & $\begin{array}{l}\text { Number of sample, } \\
\text { detail of sample }\end{array}$ & $\begin{array}{l}\text { Method of } \\
\text { the study }\end{array}$ & $\begin{array}{l}\text { Variants } \\
\text { genotype of } \\
\text { CYP2C9 }\end{array}$ & Outcome therapy & Result \\
\hline \multirow[t]{2}{*}{1.} & \multirow[t]{2}{*}{$\begin{array}{l}\text { Influence of CYP2C9 } \\
\text { gene polymorphisms } \\
\text { on response to } \\
\text { glibenclamide in type } \\
2 \text { diabetes mellitus } \\
\text { patients [7] }\end{array}$} & \multirow{2}{*}{$\begin{array}{l}80 \text { patients : } \\
78 \text { patients: } \\
\text { combination } \\
\text { treatment } \\
\text { (glibenclamide and } \\
\text { metformin) } \\
2 \text { patients: } \\
\text { monotherapy } \\
\text { (glibenclamide) }\end{array}$} & \multirow[t]{2}{*}{ cohort } & $\begin{array}{l}\text { 64 patients: } \\
* 1 / * 1\end{array}$ & $\begin{array}{l}25 \% \text { controlled diabetes } \\
75 \% \text { uncontrolled } \\
\text { diabetes }\end{array}$ & \multirow{2}{*}{$\begin{array}{l}\text { Variants genotype } \\
\text { CYP2C9 }(* 1 / * 2 \text { and } \\
* 1 / * 3) \text { is related to } \\
\text { controlled diabetes, } \\
\text { while normal } \\
\text { genotype CYP2C9 } \\
(* 1 / * 1) \text { is related to } \\
\text { uncontrolled } \\
\text { diabetes. }\end{array}$} \\
\hline & & & & $\begin{array}{l}15 \text { patients: } \\
* 1 / * 3 \\
1 \text { patients: } \\
* 1 / * 2\end{array}$ & $\begin{array}{l}50 \% \text { controlled diabetes } \\
50 \% \text { uncontrolled } \\
\text { diabetes }\end{array}$ & \\
\hline \multirow[t]{5}{*}{2.} & \multirow{5}{*}{$\begin{array}{l}\text { CYP2C9, KCNJ11 } \\
\text { and ABCC8 } \\
\text { polymorphisms and } \\
\text { the response to } \\
\text { sulphonylurea } \\
\text { treatment in type } 2 \\
\text { diabetes patients [8] }\end{array}$} & \multirow{2}{*}{$\begin{array}{l}156 \text { patients : } \\
135 \text { patients: } \\
\text { combination } \\
\text { treatment } \\
\text { (sulfonylurea and } \\
\text { metformin) }\end{array}$} & \multirow[t]{5}{*}{ cohort } & $\begin{array}{l}96 \text { patients: } \\
* 1 / * 1\end{array}$ & $\begin{array}{l}18 \text { patients }(56.3 \%) \text { with } \\
\text { hypoglycemic } \\
78 \text { patients }(62.9 \%) \\
\text { without hypoglycemic }\end{array}$ & \multirow{5}{*}{$\begin{array}{l}\text { Association of } \\
\text { CYP2C9 (as a gene } \\
\text { which metabolize } \\
\text { sulphonyilurea) } \\
\text { polymorphism and } \\
\text { hypoglycaemia } \\
\text { episode was not } \\
\text { significant in DMT2 }\end{array}$} \\
\hline & & & & $\begin{array}{l}30 \text { patients: } \\
* 1 / * 2\end{array}$ & $\begin{array}{l}7 \text { patients }(21.9 \%) \text { with } \\
\text { hypoglycemic } \\
23 \text { patients }(18.6 \%) \\
\text { without hypoglycemic }\end{array}$ & \\
\hline & & \multirow[t]{3}{*}{$\begin{array}{l}21 \text { patients: } \\
\text { monotherapy } \\
\text { (sulfonylurea) }\end{array}$} & & $\begin{array}{l}21 \text { patients: } \\
* 1 / * 3\end{array}$ & $\begin{array}{l}5 \text { patients }(15.6 \%) \text { with } \\
\text { hypoglycemic } \\
16 \text { patients }(12.9 \%) \\
\text { without hypoglycemic }\end{array}$ & \\
\hline & & & & $\begin{array}{l}3 \text { patients: } \\
* 2 / * 2\end{array}$ & $\begin{array}{l}0 \text { patients }(0 \%) \text { with } \\
\text { hypoglycemic } \\
3 \text { patients }(2.4 \%) \\
\text { without hypoglycemic }\end{array}$ & \\
\hline & & & & $\begin{array}{l}6 \text { patients: } \\
* 2 / * 3\end{array}$ & $\begin{array}{l}2 \text { patients }(6.2 \%) \text { with } \\
\text { hypoglycemic } \\
4 \text { patients }(3.2 \%) \\
\text { without hypoglycemic }\end{array}$ & \\
\hline 3. & $\begin{array}{l}\text { Effect Of Cytochrome } \\
\text { P450 2c9 Gene } \\
\text { Polymorphisms On } \\
\text { Individual Sensitivity } \\
\text { To Gliclazide In } \\
\text { Patients With Type 2 } \\
\text { Diabetes Mellitus [9] }\end{array}$ & $\begin{array}{l}74 \text { patients using } \\
\text { monotherapy } \\
\text { (gliclazide) }\end{array}$ & & $\begin{array}{c}6 \text { patients: } \\
* 1 / * 1 \\
14 \text { patients: } \\
* 1 / * 2 \\
11 \text { patients: } \\
* 1 / * 3 \\
1 \text { patients: } \\
* 2 / * 2 \\
2 \text { patients: } \\
* 2 / * 3\end{array}$ & $\begin{array}{l}\text { All patients with } \\
\text { variants genotype of } \\
\text { CYP2C9 achieved the } \\
\text { HbA1c target }\end{array}$ & $\begin{array}{l}\text { Patients with wild- } \\
\text { type allele had lower } \\
\text { effective dose of } \\
\text { gliclazide rather than } \\
\text { patients who had a } \\
\text { polymorphic allele } \\
\text { of CYP2C9, which } \\
\text { usually use high } \\
\text { dose (90-120 mg) of } \\
\text { drug. }\end{array}$ \\
\hline 4. & $\begin{array}{l}\text { CYP2C9*3 gene } \\
\text { variant contributes } \\
\text { independently to } \\
\text { glycemic control in } \\
\text { patients with type } 2\end{array}$ & $\begin{array}{l}\text { 404 patients : } \\
\text { Monotherapy } \\
\text { (Glibenclamide) or } \\
\text { combination } \\
\text { treatment }\end{array}$ & $\begin{array}{l}\text { cross- } \\
\text { section }\end{array}$ & $\begin{array}{l}\text { CYP2C } 9 * 2, \\
\text { variants } * 1 / * 1\end{array}$ & $\begin{array}{l}153 \text { patients has good } \\
\text { glycemic control }\end{array}$ & $\begin{array}{l}\text { Variants CYP2C9*3 } \\
\text { has a correlation } \\
\text { with good glycemic } \\
\text { index rather than } \\
\text { variants CYP2C } 9 * 2\end{array}$ \\
\hline
\end{tabular}




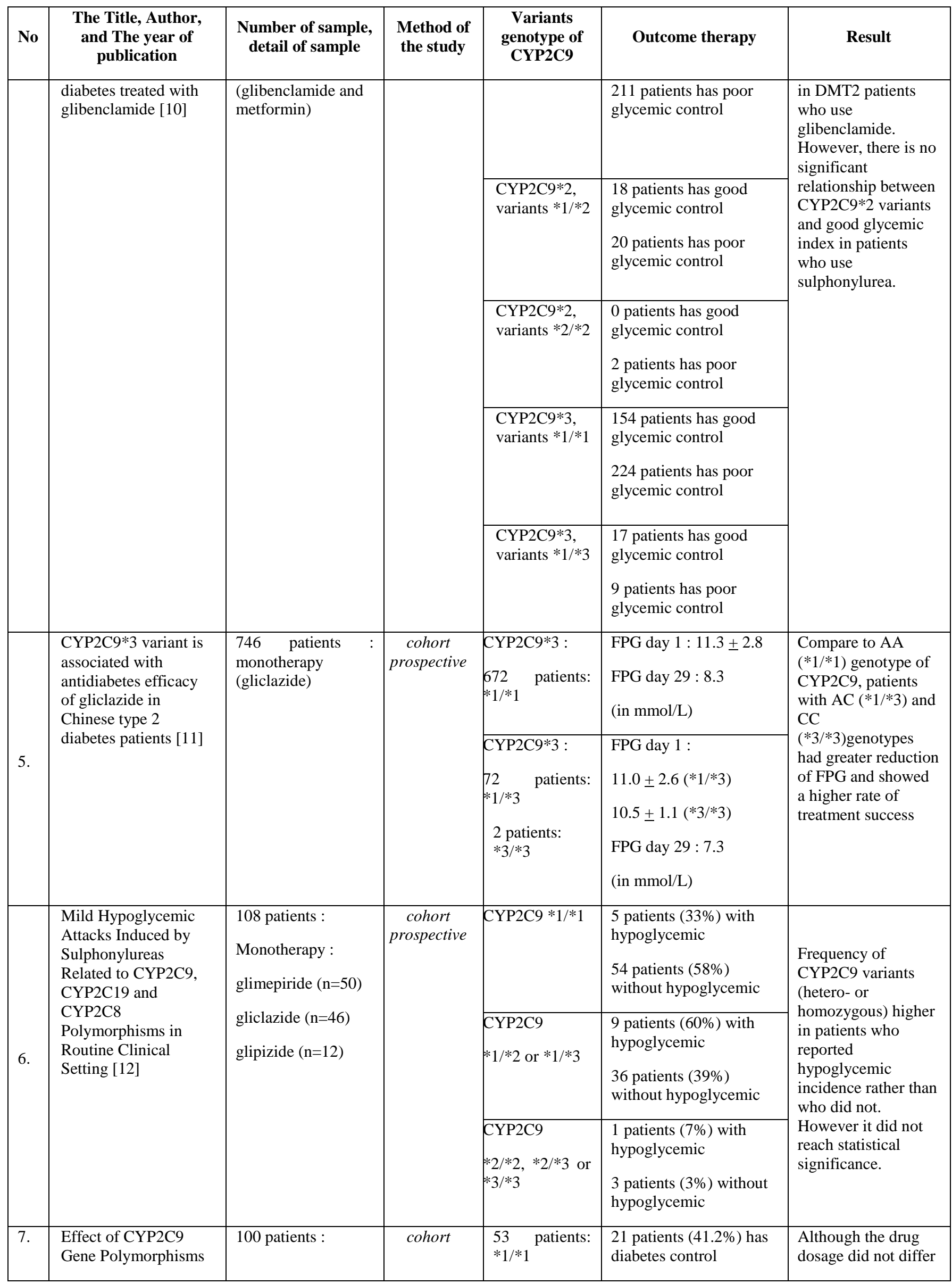




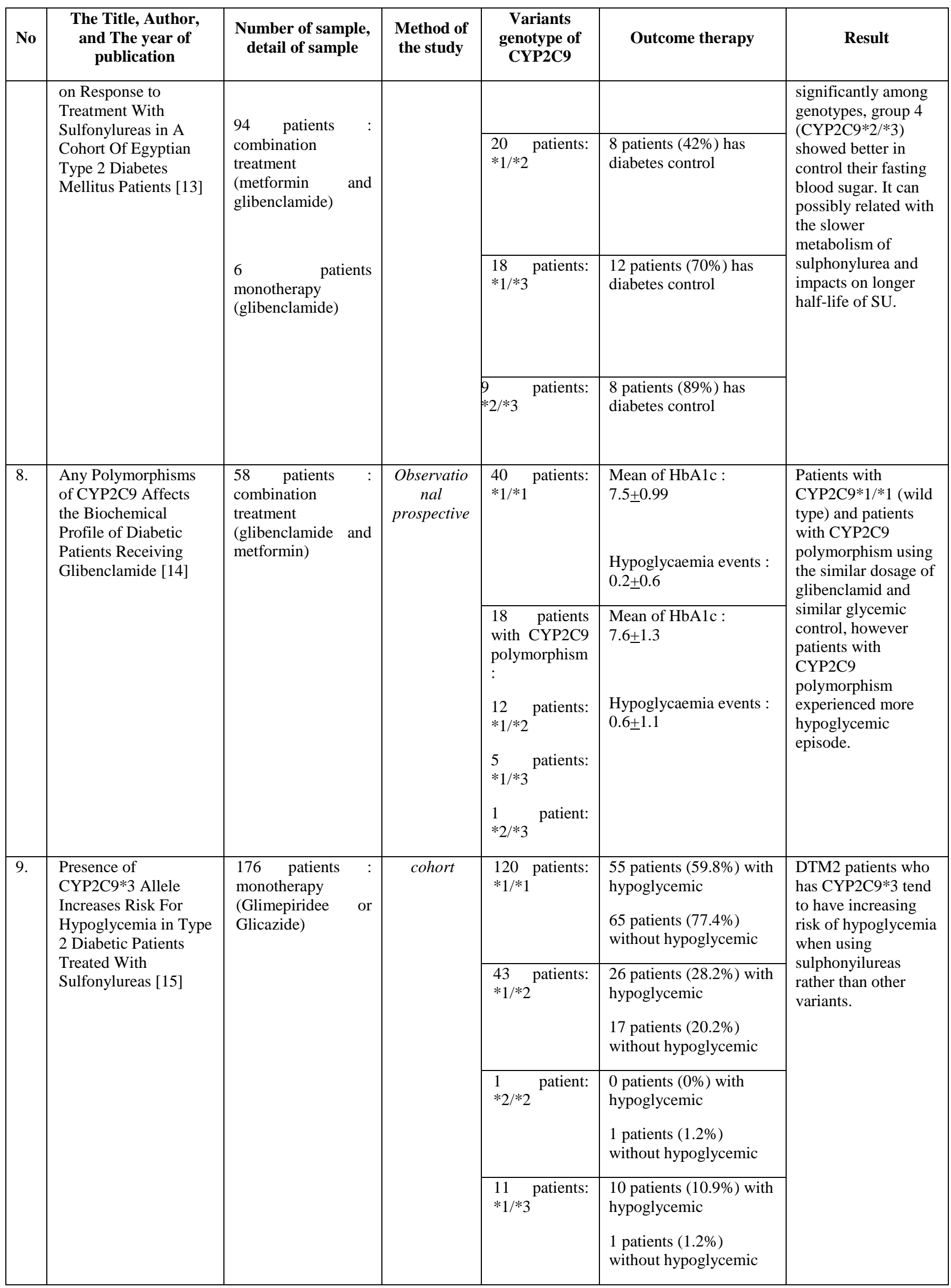




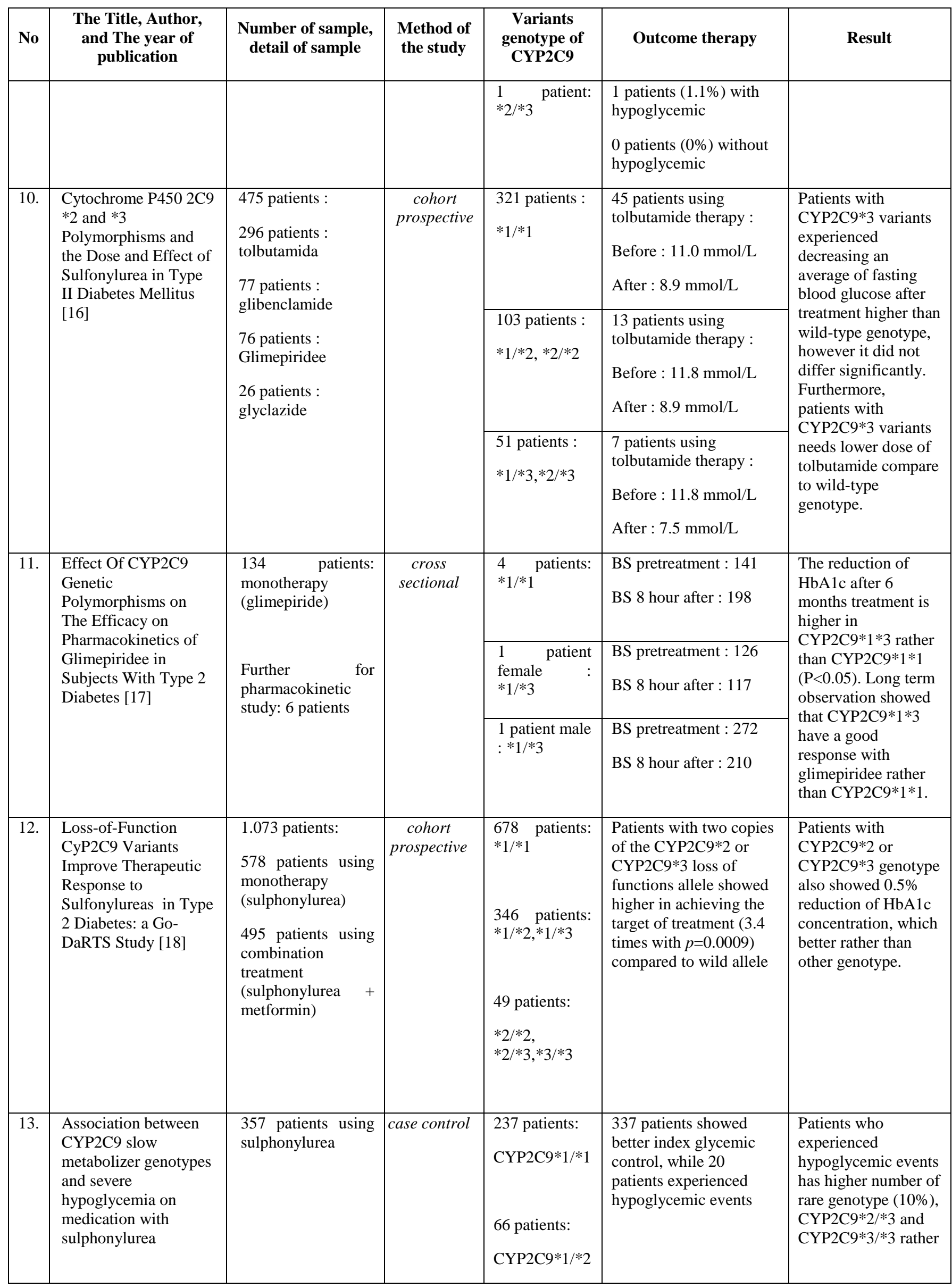




\begin{tabular}{|c|c|c|c|c|c|c|}
\hline No & $\begin{array}{c}\text { The Title, Author, } \\
\text { and The year of } \\
\text { publication }\end{array}$ & $\begin{array}{l}\text { Number of sample, } \\
\text { detail of sample }\end{array}$ & $\begin{array}{l}\text { Method of } \\
\text { the study }\end{array}$ & $\begin{array}{l}\text { Variants } \\
\text { genotype of } \\
\text { CYP2C9 }\end{array}$ & Outcome therapy & Result \\
\hline & $\begin{array}{l}\text { hypoglycemic agents } \\
\text { [19] }\end{array}$ & & & $\begin{array}{l}5 \text { patients: } \\
\text { CYP2C } 9 * 2 / * 2 \\
40 \text { patients: } \\
\text { CYP2C } 9 * 1 / * 3 \\
6 \text { patients: } \\
\text { CYP2C } 9 * 2 / * 3 \\
3 \text { patients: } \\
\text { CYP2C } 9 * 3 / * 3\end{array}$ & & $\begin{array}{l}\text { than patient without } \\
\text { hypoglycemia ( } 2 \%)\end{array}$ \\
\hline
\end{tabular}

The articles showed the relationship between genotype variance with outcome therapy and the effect of therapy such as the hypoglycemia effect after the treatment. The outcome therapy of the articles varied and include factors such as fasting blood glucose (FBG), blood glucose (BG) or Haemoglobin A1c (HbA1C). The FBG is one of glycemic index parameters measured after the patients fasted for at least 8 hours, in comparison to BG that can be measured anytime. $\mathrm{HbA} 1 \mathrm{c}$ is measured to determine the average BG within 2-3 months.

\section{DISCUSSION}

The first study from Surendiran et al. [7] showed that $75 \%$ of patients in normal genotype group (CYP2C9*1/*1) had uncontrolled diabetes status and $50 \%$ of patients in variants genotype (CYP2C $9 * 1 / * 2$ and CYP2C $9 * 1 / * 3)$ also faced uncontrolled diabetes status. The results showed the significant relationship between variants genotype CYP2C9 with controlled diabetes status and between normal genotype with uncontrolled diabetes status. This study also demonstrated that variants genotype is related to good response of diabetic control in patients who use glibenclamide than those in normal genotype. Another outcome is related to hypoglycemic effect with the use of glibenclamide, displaying that variants genotype was not related to adverse effect or hypoglycemic events.

A second study, from Klen et al. [8] showed that there is no significant correlation between variants genotype of CYP2C9 with diabetes index and with hypoglycemic episode. The average HbAlc achieves the target of $7.0 \pm 0.9$ and hypoglycemic episodes occurred in 32 patients $(20.51 \%)$. On average, patients with two wild-type alleles faced $0.390 \pm 0.982$ hypoglycemic events, in comparison to those who faced increased hypoglycemic events $(0.550 \pm 0.55$ in one polymorphic allele and $1.22 \pm 2.728$ in two polymorphic alleles). Other results from this study included that geriatric patients (>60 years) have a higher risk to face significant hypoglycemic events. Geriatric patients with two wild-type alleles experienced $0.36+0.98$ events, while patients with one polymorphic allele experienced $0.79 \pm 1.7$ events and patients with two polymorphic allele experienced $2.67 \pm 4.6$ events $(\mathrm{p}$ $=0.014)$. This study concluded that the CYP2C9 polymorphism was not related significantly to diabetes index, however CYP2C9 genotype may influence the risk of hypoglycemia in geriatric patients.

The next study discussed the impact of CYP2C9 polymorphism on individual sensitivity to the use of gliclazide [9]. Results of this study showed that 46 patients $(62.16 \%)$ had normal genotype of CYP2C9 $* 1 / * 1$ and allele polymorphisms, whether heterozygote (CYP2C $9 * 1 / * 2$, CYP2C $9 * 1 / * 3, \quad$ CYP2C $9 * 2 / * 3) \quad$ or homozygote $(\mathrm{CYP} 2 \mathrm{C} 9 * 2 / * 2)$, was found in 28 patients $(37.84 \%)$. This study showed that variants genotype has a correlation with individual response of the drug, and will affect BG. Patients who have polymorphic allele of CYP2C9 (homo- or heterozygous) relate to the decreasing dose of gliclazide and using it as a monotherapy agent for DMT2.

A research study by Castelan-Martinez et al. [10] found that the genotypes and allelic frequencies in Mexican patients were CYP2C9*2 CC, CT, TT and CYP2C9*3 AA, AC. This study showed that DMT2 patients with CYP2C9*3 variants have good glycemic control rather than patients who have CYP2C $9 * 2$ variants, and the relationship maintained after adjustment.

Another study from China showed that the largest frequencies of CYP2C $9 * 3$ genotype was AA $(* 1 / * 1)$, which is $90.08 \%$ [11]. Results of this study showed that the polymorphism of CYP2C9*3 was significantly related to the diabetic index (FBG) as an outcome of DMT2 treatment.

Other study from Turkey showed the impact of CYP2C9 polymorphism on hypoglycemia [12]. Results of this study showed that patients with genotype variants of CYP2C9 tend to experience hypoglycemic effects, highly impacting patients who use gliclazide as a DMT2 treatment.

The next study determined the impact of CYP2C9 polymorphism on response of treatment in Egyptian patients with DMT2 [13]. The genotype frequencies are 53 patients who were carriers of CYP2C $9 * 1 / * 1$ (wild-type), 20 patients who were carriers of CYP2C $9 * 1 / * 2$ (heterozygous for 
CYP2C $9 * 2$ ), 18 carriers of CYP2C $9 * 1 / * 3$ (heterozygous for CYP2C $9 * 3$ ) and 9 patient carriers of CYP2C $9 * 2 / * 3$ (double heterozygous for both mutant alleles). Better diabetes control was observed using FBG and found to be higher in patients with carriers CYP2C9*2/*3 genotype. This study assumed that CYP2C $9 * 2 / * 3$ genotype caused slower SU metabolism and extended its half-life.

A research study from Koren et al. [14], showed that the outcome therapy in each genotype did not differ significantly, however related to hypoglycemic event, patients with CYP2C9 polymorphism experienced higher hypoglycemic events after three months of treatment with glibenclamide (22.2\% events in more than two hypoglycemic episodes). Meanwhile, patients with normal genotype only experienced $5 \%$ of events during three months of treatment and using the same dosage as others.

A study performed by Ragia, et al. [15] showed that the frequency of patients with CYP2C9 polymorphism was $31.8 \%$ from 176 total samples. In this study, patients with genotype polymorphism experienced hypoglycemia higher than other genotypes. Of patients with the CYP2C9*3 allele, 11 patients (12\%) experienced hypoglycemia, while only one patient did not. Patients who have CYP 2 C $9 * 1 / * 3$ genotype showed statistically significant increased hypoglycemia risk after adjusted analysis $(\mathrm{p}=0.011)$, however no differences in CYP2C9*2 allele related to hypoglycemic event.

Another study, from Becker et al. [16], aimed to determine the association between CYP2C9 polymorphism with glucose level and prescribed doses of sulphonylureas. Most patients were treated using tolbutamide and a larger genotype frequency is CYP2C9 $* 1 / * 1$. The result showed that patients who have CYP2C $9 * 3$ polymorphism have an average higher number of decreases in FBG after a certain duration of treatment. Although it is not significantly different $(\mathrm{p}=0.11)$, CYP2C9*3 patients require lower prescription doses compared to wild-type patients. Furthermore, patients with other genotypes did not differ significantly in term of prescribed doses of tolbutamide compared to wild-type patients.

Results of a study by Suzuki et al. [17] showed that patients with genotype variants CYP2C $9 * 1 / * 3$ have a good response to glimepiride rather those with normal genotype. However, one patient experienced a gain in body weight after treatment with glimepiride.

In research from Zhou et al, [18], patients with genotype CYP 2 C $9 * 2 / * 2$ or CYP 2 C $9 * 2 / * 3$ or CYP 2 C $9 * 3 / * 3$ had a $0.5 \%$ better reduction of $\mathrm{HbA} 1 \mathrm{c}$ rather than wild-type patients, specifically in CYP2C $9 * 2 / * 3$ genotype. Patients with CYP2C9*2/*3 genotype was known can achieve target treatment 7.54 times $(p=0.003)$ rather than normal genotype. Patients with CYP2C9*2 showed slight overrepresentation in a non-tolerant group, however it still hard to draw the conclusion. In general, CYP2C9 loss-of-function variants relate to the greater response to sulphonylureas and lower rate of failure.

A research study from Holstein et al. [19] showed that 20 DMT2 patients who use sulphonylureas experienced hypoglycemia in the following details: $13(65 \%)$ from patients who had CYP2C $9 * 1 / * 1,4(20 \%)$ from patients who had $\mathrm{CYP} 2 \mathrm{C} 9 * 1 / * 2$, one patient for each genotype
CYP2C $9 * 1 / * 3 \quad(5 \%), \quad$ CYP2C $9 * 2 / * 3 \quad(5 \%), \quad$ and CYP2C $9 * 3 / * 3(5 \%)$, however no hypoglycemic cases in genotype CYP2C $9 * 2 / * 2$. This study also presented that age plays a role in the hypoglycemic event. The mean age of the diabetic control patients (337 patients) was 65 years, while in 20 DMT2 patients who experienced hypoglycemia mean age was 74 years.

In general, result of variants genotype from genotyping analysis on 13 research studies are CYP2C9*2 (rs1799853), CYP2C9*3 (rs1057910) and CYP2C9*1/*1 (wild-type). There are two types of CYP2C $9 * 2$ which are homozygous, CYP2C9*2/*2 (consisting of two identical alleles or perform polymorphism in both alleles), and heterozygous, CYP2C $9 * 1 / * 2$ (consisting of two different alleles or perform polymorphism in one allele). Others include CYP2C $9 * 3$ with homozygote variant CYP2C9*3/*3 and heterozygous variant CYP2C $9 * 1 / * 3$. Genotype heterozygote CYP2C $9 * 2 / * 3$ also found in some subjects.

The total patients from 13 articles reviewed was 3941 DMT2 patients. Patients with wild-type genotype perform in $72.47 \%$ DMT2 patients from the aforementioned articles. Variants genotype CYP2C $9 * 3 / * 3$ is the rarest, which affects only 12 patients from 3941 patients $(0.30 \%)$. Patients with heterozygous genotypes, such as CYP2C9*1/*2 or CYP2C $9 * 1 / * 3$, affects approximately 971 patients $(24.64 \%)$, while homozygous genotypes, such as CYP2C $9 * 2 / * 2$, CYP2C $9 * 2 / * 3$ or CYP2C $9 * 3 / * 3$, are found in only 114 patients.

Based on the performed literature review, further studies are needed to find the clear impact of CYP2C9 polymorphism, especially in Indonesia, which has a higher incidence of DMT2. Genetic and other factors can be associated with the patients' response to oral antidiabetics and impact the outcome, whether due to glycemic index or side effect.

MSWord. The font in the row header should be bold and you can use the style available from the style palette.

\section{AUTHORS' CONTRIBUTIONS}

NM, DAP, INF: search the articles; HD: data extraction; LMH, RM: Critical appraisal; NM, DAP: manuscript draft; INF, LMH, RM: manuscript revision

\section{ACKNOWLEDGMENTS}

Authors thank to the Head of Undergraduate Program of Faculty of Pharmacy, Universitas Ahmad Dahlan for the permition in conducting the literature review.

\section{REFERENCES}

[1] Piteto, A., 2015, Health Education in the Management of Diabetes at the Primary Health Care Level: is there a Gender Differens?. Eastern Mediterranean Health Journal [http://search.proquest.com] accessed on 7 September 2018 
[2] Riskesdas, 2018, Laporan Hasil Riset Kesehatan Dasar (RISKESDAS) Nasional. Jakarta: Badan Penelitian dan Pengembangan Kesehatan

[3] Kemenkes RI, 2019, Hari Diabetes Sedunia 2018, Pusat Data dan Informasi Kemenkes RI, Jakarta Selatan

[4] Bolen, S.; Feldman, L.; Vassy, J.; Wilson, L.; Yeh, H.C.; Marinopoulos, S.; Wiley, C.; Selvin, E.; Wilson, R.; Bass, E.B.; Brancati, F.L., 2007, Narrative review: comparative effectiveness and safety of oral medications for type 2 diabetes mellitus. Ann. Intern. effectiveness and safety of oral medications for type 2 diabetes mellitus., Ann. Intern. Med., 147( 6), 386-399.

[5] PERKENI, 2011, Konsensus Pengelolaan dan Pencegahan DM Tipe 2 di Indonesia . PERKENI, Jakarta

[7] Surendiran, A. S. C. Pradhan, S. Rajan, D. Anichavezhi, C. Adithan, 2011, Influence of CYP2C9 gene polymorphisms on response to glibenclamide in type 2 diabetes mellitus patients, Eur J Clin Pharmacol.

[8] Klen, J., Dolžan, V. and Janež, A., 2014, CYP2C9, $\mathrm{KCNJ} 11$ and $\mathrm{ABCC} 8$ polymorphisms and the response to sulphonylurea treatment in type 2 diabetes patients. European journal of clinical pharmacology, 70(4), pp.421-428.

[9] Abulula, M., Baranov, V.L. and Vorokhobina, N.V., 2015, Effect Of Cytochrome P450 2c9 Gene Polymorphisms On Individual Sensitivity To Gliclazide In Patients With Type 2 Diabetes Mellitus. Herald of North-Western State Medical University named after II Mechnikov, 7(1), pp.28-33.

[6] Elliot, D.J.; Suharjono.; Lewis, B.C.; Gillam, E.M.; Birkett, D.J.; Gross, A.S.; Miners, J.O., 2007, Identification of the human cytochromes P450 catalysing the rate-limiting pathways of gliclazide elimination. Br. J. Clin. Pharmacol., 64( 4), 450-457.

[10] Castelán-Martínez, O.D., Hoyo-Vadillo, C., Bazán-Soto, T.B., Cruz, M., Tesoro-Cruz, E. and Valladares-Salgado, A., 2018, CYP2C9* 3 gene variant contributes independently to glycemic control in patients with type 2 diabetes treated with glibenclamide: Journal of clinical pharmacy and therapeutics, 43(6), pp.768-774.

[11] Zeng, W., Guo, Y., Chen, P., Liu, Z., Chen, D. and Han, C., 2016, CYP 2C93 variant is associated with antidiabetes efficacy of gliclazide in Chinese type 2 diabetes patients, Journal of diabetes investigation, 7(5), pp.764-768.

[12] Gökalp, O., Gunes, A., Çam, H., Cure, E., Aydın, O., Tamer, M.N., Scordo, M.G. and Dahl, M.L., 2011, Mild hypoglycemic attacks induced by sulphonylureas related to CYP2C9, CYP2C19 and CYP2C8 polymorphisms in routine clinical setting. European journal of clinical pharmacology, 67(12), pp.1223-1229.

[13] Salam, R.F.A., Zeyada, R. and Osman, N.A., 2014, Effect of CYP2C9 gene polymorphisms on response to treatment with sulfonylureas in a cohort of Egyptian type 2 diabetes mellitus patients. Comparative Clinical Pathology, 23(2), pp.341-346.

[14] Koren, S., Koren, R., Bar-Chaim, A., BenvenisteLevkovitz, P. and Golik, A., 2015, Any polymorphisms of CYP2C9 affects the biochemical profile of diabetic patients receiving glibenclamide. Clin. Med. Biochem. Open Access, 1, p.102.

[15] Ragia, G., Petridis, I., Tavridou, A., Christakidis, D. and Manolopoulos, V.G., 2009, Presence of CYP2C9* 3 allele increases risk for hypoglycemia in Type 2 diabetic patients treated with sulfonylureas. Pharmacogenomics, 10(11), pp.1781-1787.

[16] Becker, M.L., Visser, L.E., Trienekens, P.H., Hofman, A., Van Schaik, R.H.N. and Stricker, B., 2008, Cytochrome $\mathrm{P} 450$ 2C9* 2 and* 3 polymorphisms and the dose and effect of sulfonylurea in type II diabetes mellitus. Clinical Pharmacology \& Therapeutics, 83(2), pp.288-292.

[17] Suzuki, K., Yanagawa, T., Shibasaki, T., Kaniwa, N., Hasegawa, R. and Tohkin, M., 2006, Effect of CYP2C9 genetic polymorphisms on the efficacy and pharmacokinetics of glimepiridee in subjects with type 2 diabetes. Diabetes research and clinical practice, 72(2), pp.148-154.

[18] Zhou, K., Donnelly, L., Burch, L., Tavendale, R., Doney, A.S.F., Leese, G., Hattersley, A.T., McCarthy, M.I., Morris, A.D., Lang, C.C. and Palmer, C.N.A., 2010, Loss-of-function CYP2C9 variants improve therapeutic response to sulfonylureas in type 2 diabetes: a GoDARTS study, Clinical Pharmacology \& Therapeutics, 87(1), pp.52-56.

[19] Holstein, A., Plaschke, A., Ptak, M., Egberts, E.H., ElDin, J., Brockmöller, J. and Kirchheiner, J., 2005. Association between CYP2C9 slow metabolizer genotypes and severe hypoglycaemia on medication with sulphonylurea hypoglycemic agents. British journal of clinical pharmacology, 60(1), pp.103-106. 